\title{
Het Europees Openbaar Ministerie tussen soevereiniteit en effectiviteit
}

\author{
Mr. dr. W. Geelhoed*
}

Het voorstel van de Europese Commissie voor oprichting van een Europees Openbaar Ministerie hinkt op twee gedachten. Het streven is de fraudebestrijding voortvarender te maken, maar tegelijk niet ten koste van nationale strafvorderlijke autonomie te laten gaan. Wanneer nationale strafrechtelijke gevoeligheden koste wat kost worden gespaard, kan slechts een papieren tijger worden opgericht. Dan is het beter om ofwel niets te doen, ofwel een krachtige instelling op te richten die daadwerkelijk strafrechtelijke bescherming biedt voor de financiële belangen van de EU.

Voorstel voor een verordening van de Raad tot instelling van het Europees Openbaar Ministerie, COM(2013)534

\section{Inleiding}

De Europese Commissie publiceerde op 17 juli 2013 een voorstel voor een verordening tot oprichting van het Europees Openbaar Ministerie (hierna: Europees OM), op grondslag van artikel 86 VWEU. Deze instelling zou een krachtdadig strafrechtelijk optreden moeten verzekeren ter bescherming van de financiële belangen van de Europese Unie. Het gedeelte van het EU-budget dat jaarlijks door fraude en andere onregelmatigheden niet op de juiste wijze wordt besteed, zou daardoor moeten afnemen tot een aanvaardbaar niveau. Om een dergelijk orgaan te realiseren, moeten echter aanzienlijke aarzelingen bij de lidstaten worden overwonnen. De introductie van een Europese instantie die zelfstandig beslist over het instellen van strafrechtelijke vervolging, kan in de lidstaten worden gezien als een aantasting van nationale soevereiniteit. Oprichting van een Europees OM is volgens artikel 86 VWEU slechts mogelijk bij unanimiteit in de Raad, maar als die niet kan worden verkregen kan ook een groep van minstens negen lidstaten tot oprichting overgaan. Vanwege de grote aarzelingen bij enkele

Mr. dr. W. (Pim) Geelhoed is als universitair docent straf- en strafprocesrecht verbonden aan de Universiteit Leiden. lidstaten zal een realistisch scenario daarom zijn dat het Europees OM slechts bij nauwere samenwerking kan worden opgericht. Dat geeft de lidstaten die veel belang hechten aan zeggenschap over opsporing en vervolging de ruimte om niet deel te nemen, zonder dat die beslissing de oprichting van een Europees OM in de weg staat.

De spagaat tussen aan de ene kant de behoefte aan effectieve fraudebestrijding en aan de andere kant het belang van autonomie van de nationale strafrechtshandhaving, komt duidelijk naar voren uit het Commissievoorstel. Op verschillende punten zijn er in het voorstel flinke concessies gedaan omwille van de politieke haalbaarheid, waarvoor de Commissie dus niet de formele onderhandelingen met de Raad heeft willen afwachten. Niet het gehele voorstel wordt behandeld in deze bijdrage. Achterwege blijven bijvoorbeeld gegevensbescherming en de rechterlijke toetsing van (vervolgings)beslissingen van het Europees OM. Achtereenvolgens wordt stilgestaan bij de institutionele inbedding van de organisatie en daarmee samenhangend de rechtsgrondslag voor oprichting, de materiële reikwijdte van de competentie van het Europees OM, de strafvorderlijke bevoegdheden die het zou kunnen uitoefenen en de inkadering van de vervolgingsbeslissing. Daarmee staan de klassieke taken die een vervolgingsautoriteit zou moeten vervullen centraal. Een kritische blik wordt geworpen op de voorstellen in het licht van de effectiviteit van fraudebestrijding en autonomie van het nationale strafrecht. Daarbij wordt ook aandacht gegeven aan de eerste reacties op het Commissievoorstel, waaronder de bezwaren van het Nederlandse parlement. Overigens heeft de Commissie deze bezwaren inmiddels opzijgeschoven. ${ }^{1}$ Voorlopig is het dossier nog in behandeling in de werkgroepen in de Raad, heeft de Europese Commissie aangekondigd het voorstel aan te passen in reactie op de subsidiariteitsbezwaren, en vindt de Nederlandse rege-

1. Mededeling van de Commissie aan het Europees Parlement, de Raad en de nationale parlementen over de heroverweging van het voorstel voor een verordening van de Raad tot instelling van het Europees Openbaar Ministerie wat betreft het subsidiariteitsbeginsel, overeenkomstig protocol nr. 2, COM(2013)851. 
ring in afwachting daarvan een uitgebreide bespreking van het voorliggende ontwerp niet wenselijk. ${ }^{2}$

\section{Institutionele inbedding}

De rechtsgrondslag voor oprichting van het Europees OM bepaalt dat het primair bevoegd zal zijn voor het opsporen en vervolgen van strafbare feiten die de financiële belangen van de EU schaden (art. 86 VWEU). Daaruit komt naar voren dat het middel van het Europees OM vooral een middel is ter bestrijding van fraude en corruptie met EU-subsidies. Sinds lange tijd wordt daarover gediscussieerd, ook in Nederland, waarbij strafrechtelijke middelen geregeld worden genoemd. ${ }^{3}$ Het middel van het Europees OM is voorgesteld in het rapport van het zogeheten Corpus Furis-project. ${ }^{4}$ De Europese Commissie stelde voor om in het Verdrag van Nice een rechtsgrondslag voor oprichting van een Europees $\mathrm{OM}$ op te nemen, ${ }^{5}$ maar was daarin onsuccesvol. Daarop volgden een Groenboek ${ }^{6}$ en een vervolgrapport. ${ }^{7}$ Uiteindelijk werd in de Europese Grondwet een rechtsgrondslag opgenomen over het Europees OM, ${ }^{8}$ die met enkele wijzigingen, vooral ten aanzien van het unanimiteitsvereiste, na inwerkingtreding van het Verdrag van Lissabon terug te vinden is in artikel 86 VWEU. De rechtsgrondslag maakt het wel mogelijk om het Europees OM een bevoegdheid te verlenen over nader te bepalen vormen van ernstige criminaliteit met een grensoverschrijdende dimensie, maar daarover dient de Europese Raad in unanimiteit te beslissen. Voorop blijft staan dat de voornaamste taak de strafrechtelijke

2. Kamerstukken / 2013/14, 33709, nr. F, p. 5-6.

3. Bijvoorbeeld H. de Doelder (red.), Bestrijding van EEG-fraude, Arnhem: Gouda Quint 1990; J.A.E. Vervaele, Strijd tegen BTW-fraude in de Europese Unie. Handhaving in Belgie en Nederland, Antwerpen: Maklu 1995; S. White, Protection of the Financial Interests of the European Communities: The Fight Against Fraud and Corruption, Den Haag: Kluwer Law International 1998; J.A.E. Vervaele e.a., Administratieve en strafrechtelijke samenwerking inzake fraudebestrijding tussen justitiële en bestuurlijke instanties van de EU-lidstaten: eindrapport, Den Haag: WODC 2001; R.A. Wolf, Carrouselfraude. Een Europees probleem vanuit Nederlands perspectief. Een analyse van fiscale regelgeving en jurisprudentie (diss. Groningen), Den Haag: Sdu Uitgevers 2010; J.E. van den Brink, De uitvoering van Europese subsidieregelingen in Nederland. Juridische knelpunten en uitdagingen (diss. Leiden), Deventer: Kluwer 2012.

4. M. Delmas-Marty, Corpus Juris: portant dispositions pénales pour la protection des intérêts financiers de I'Union européenne, Parijs: Economica 1997; M. Delmas-Marty en J.A.E. Vervaele (red.), The Implementation of the Corpus Juris in the Member States, Antwerpen: Intersentia 2000-2001 (vier delen).

5. Mededeling van de Commissie. Aanvullende bijdrage van de Commissie ten behoeve van de Intergouvernementele Conferentie over de institutionele vraagstukken. De strafrechtelijke bescherming van de financiële belangen van de Gemeenschap: een Europese officier van justitie. $\operatorname{COM}(2000) 608$.

6. Groenboek inzake de strafrechtelijke bescherming van de financiële belangen van de Gemeenschap en de instelling van een Europese officier van justitie, $\operatorname{COM}(2001) 715$.

7. Vervolgverslag over het Groenboek inzake de strafrechtelijke bescherming van de financiële belangen van de Gemeenschap en de instelling van een Europese officier van justitie, COM(2003)128.

8. Art. III-274 van het Verdrag tot vaststelling van een Grondwet voor Europa. bescherming van de financiële belangen van de Unie zal moeten zijn.

De Commissie neemt als uitgangspunt dat die taak exclusief door het Europees OM zou moeten worden uitgeoefend, en niet door de nationale instanties. ${ }^{9}$ Dat zou een noodzakelijke voorwaarde zijn om een samenhangend en op Europees niveau stuurbaar opsporingsen vervolgingsbeleid te voeren. ${ }^{10}$ Wanneer echter in samenloop met feiten waarvoor het Europees OM exclusief bevoegd is, feiten worden gepleegd waarvoor het geen bevoegdheid bezit, zoals valsheid in geschrift, zou het Europees OM voor die feiten ook bevoegd moeten zijn om ne bis in idem-problemen te voorkomen. ${ }^{11}$ Die keuze, die de Commissie noodzaakte om een regeling op te stellen voor feiten die onlosmakelijk verbonden zijn met de kerndelicten, lijkt bij te kunnen dragen aan de effectiviteit van de werkzaamheden. Als het Europees OM echter onvoldoende capaciteit heeft om alle feiten die onder zijn competentie vallen op te sporen en te vervolgen, kunnen de autoriteiten van de lidstaten de behandeling van de zaak niet zonder meer overnemen. ${ }^{12}$ De oplossing die daarvoor is gevonden ligt in de geïntegreerde structuur die het Europees OM zou moeten krijgen. De kern van de instelling bestaat uit een Europese aanklager, die bijgestaan wordt door vier plaatsvervangers. Dit model van een eenhoofdige leiding blijkt op weerstand te stuiten in sommige lidstaten: de eerste besprekingen in de Raad op werkgroepniveau geven blijk van de voorkeur van sommige lidstaten om het Europees OM als een college in te richten, met daarin vertegenwoordigers uit de deelnemende lidstaten. Tevens wordt daarin de exclusieve bevoegdheid van het Europees OM bekritiseerd. ${ }^{13}$

Hoe dan ook zullen de Europese aanklager en zijn plaatsvervangers moeten kunnen beschikken over een staf die volgens het voorstel voornamelijk uit de gelederen van OLAF, het fraudebestrijdingsbureau van de Europese Commissie, zal worden betrokken. ${ }^{14}$ Die keuze is bijzonder in het licht van artikel 86 VWEU, dat bepaalt dat het Europees OM zal worden opgericht 'op de grondslag van Eurojust'. Dat element van de rechtsgrondslag is in het Commissievoorstel verwerkt door het Europees OM gebruik te laten maken van de fysieke en ondersteunende faciliteiten van Eurojust. ${ }^{15}$ Dat maakt het overigens zeer waarschijnlijk dat het Europees OM in de directe nabijheid van Eurojust zal worden gevestigd. Een duidelijke institutionele verbinding tussen het Europees OM en Eurojust, zoals bijvoorbeeld de opname van de Europese aanklager in het college van Euro-

9. Overweging 5 van het Commissievoorstel.

10. Overweging 23.

11. Overweging 22.

12. Kamerstukken // 2012/13, 22112, nr. 1681, p. 7

13. Verslag van de Raadswerkgroep samenwerking in strafzaken van 16 oktober 2013, doc.nr. 14914/13.

14. Zoals door de Commissie als toelichting bij de ontwerpverordening gegeven in het kader van de gevolgen voor de begroting.

15. Art. 57 lid 6 
just, is echter niet voorzien. ${ }^{16}$ Dat er volgens het Commissievoorstel een nieuwe structuur zou moeten worden opgericht naast Eurojust en OLAF, in plaats van deze bestaande structuren te versterken, was voor de Eerste en Tweede Kamer een belangrijk argument om te oordelen dat het voorstel strijdig is met het subsidiariteitsbeginsel. ${ }^{17}$ De Europese Commissie ziet echter geen heil in het versterken van bestaande structuren op Europees niveau, omdat deze geen strafrechtelijke doorzettingsmacht kunnen verkrijgen. ${ }^{18}$ Dat wil niet zeggen dat het op te richten Europees OM niet ingebed zou zijn in bestaande structuren. Een institutionele integratie wordt, in plaats van met Europese instellingen, veeleer gezocht met de nationale autoriteiten. Het geïntegreerde karakter dat het Europees OM volgens het Commissievoorstel zou moeten krijgen bestaat namelijk daarin, dat de Europese aanklager aanwijzingen kan geven aan specifiek aangewezen officieren van justitie in de aangesloten lidstaten, de 'gedelegeerde Europese aanklagers'. Deze laatsten behouden hun status als lid van het nationale OM, maar krijgen tevens een Europese status. Daardoor kan het Europees OM voor de opsporing, naast zijn eigen staf, ook rekenen op de nationale opsporingsinstanties die door de gedelegeerde Europese aanklagers worden aangestuurd. Die gedelegeerde Europese aanklagers functioneren dus in een dubbele hiërarchie, en wanneer zij conflicterende opdrachten krijgen moeten zij dit meedelen aan de Europese aanklager. Deze kan aan de gedelegeerde Europese aanklager bevelen om aan zijn Europese functie voorrang te geven. ${ }^{19}$ De Eerste en Tweede Kamer vonden het onwenselijk dat nationale opsporingsprioriteiten het onderspit delven als gevolg van de doorzettingsmacht van het Europees OM. ${ }^{20}$

Volgens het voorstel zouden de Europese aanklager en zijn vier plaatsvervangers, samen met vijf van de gedelegeerde Europese aanklagers, een bijzondere functie krijgen. Deze tien personen dienen gezamenlijk richtlijnen op te stellen voor de beslissingen die het Europees OM dient te nemen, waarbij het onder meer gaat over de keuze voor de jurisdictie waar opgespoorde strafbare feiten worden vervolgd. ${ }^{21}$ Voor het overige bezit het Europees OM weinig beleidsvrijheid, want het wordt gebonden aan het legaliteitsbeginsel en is daarmee in principe verplicht vervolging in te stellen wanneer een veroordeling haalbaar lijkt. Daarop zijn slechts beperkte uitzonderingen mogelijk. Het lijkt erop dat de keuze voor een

16. Wel zijn er in art. 57 van de ontwerpverordening regelingen voorgesteld over de onderlinge betrekkingen tussen Eurojust en het Europees $\mathrm{OM}$.

17. Kamerstukken / 2013/14, 33709, nr. C; Kamerstukken /I 2013/14, 33709, nr. 2.

18. Mededeling van de Commissie aan het Europees Parlement, de Raad en de nationale parlementen over de heroverweging van het voorstel voor een verordening van de Raad tot instelling van het Europees Openbaar Ministerie wat betreft het subsidiariteitsbeginsel, overeenkomstig protocol nr. 2, $\operatorname{COM}(2013) 851$, p. 8.

19. Art. 6 lid 6

20. Kamerstukken / 2013/14, 33709, nr. C; Kamerstukken || 2013/14, 33709 , nr. 2.

21. Art. 7. vervolgingsverplichting volgens de Commissie samenhangt met een positie van het Europees OM die in die zin onafhankelijk is van de politieke instellingen dat deze laatste geen algemene of bijzondere aanwijzingen kunnen geven. De Europese aanklager kan slechts ter verantwoording worden geroepen door het Hof van Justitie, dat hem op verzoek van het Parlement, de Raad of de Commissie kan ontslaan. ${ }^{22} \mathrm{Er}$ is dus geen mogelijkheid voorzien voor de Commissie of de Raad om aanwijzingen te geven, waardoor parlementaire controle niet gemakkelijk is. ${ }^{23}$ Gezien het feit dat in het verleden de integriteit van de Commissie zelf ook ter discussie heeft gestaan, is daar wel wat voor te zeggen. Dat er door het Europees OM beleid moet worden gevoerd staat echter buiten kijf, hetgeen ook uitdrukkelijk door de ontwerpverordening wordt erkend. Deze geeft aan dat regels voor de forumkeuze en voor het aanbieden van transacties in beleidsdocumenten moeten worden vastge$\operatorname{legd} .^{24}$

\section{Materiële reikwijdte}

Een opvallende keuze is gemaakt in de bepaling van de materieelrechtelijke reikwijdte voor de competentie van het Europees OM. De instelling zou expliciet bevoegd moeten zijn om strafbare feiten te vervolgen die zijn opgenomen in een aparte richtlijn ter harmonisatie van de bescherming van de financiële belangen van de Europese Unie (hierna: PIF-richtlijn), ${ }^{25}$ en die zijn omgezet in nationale strafbaarstellingen. ${ }^{26}$ Voor deze strafbare feiten is de precieze omvang van de competentie van het Europees OM dus afhankelijk van de implementatie in het nationale recht. Dat betekent dat verschillen tussen de nationale regelingen leiden tot uiteenlopende competentieregimes. ${ }^{27} \mathrm{Nu}$ hoeft dat niet tot grote problemen te leiden wat betreft de tekst van de nationale omzettingsbepalingen. De mogelijkheid voor de Commissie om in inbreukprocedures te reageren op gebrekkige omzetting van materieelrechtelijke bepalingen is bij een richtlijn aanzienlijk groter dan waar, zoals tot nu toe het geval is, deze materie van fraude met EU-subsidies in

22. Art. 8 en overweging $10-11$

23. Voor een discussie over democratische verantwoording door het Europees OM zie: M. Zwiers, The European Public Prosecutor's Office. Analysis of a Multilevel Criminal Justice System (diss. Maastricht), Antwerpen: Intersentia 2011, en G. Conway, 'Holding to Account a Possible European Public Prosecutor', Criminal Law Forum 2013, p. 371-401.

24. Bijvoorbeeld in overweging 12, 30 en 31.

25. Voorstel voor een richtlijn van het Europees Parlement en de Raad betreffende de strafrechtelijke bestrijding van fraude die de financiële belangen van de Unie schaadt, $\operatorname{COM}(2012) 363$.

26. Art. 12 van de ontwerpverordening.

27. Zie ook 'Note Meijers Committee on the proposed Council Regulation on the establishment of the European Public Prosecutor's Office' (CM1315), p. 2, die dat vooral als bedreiging voor de rechtsgelijkheid ziet, en A.H. Klip, 'The Substantive Criminal Law Jurisdiction of the European Public Prosecutor's Office', European Journal of Crime, Criminal Law and Criminal Justice 2012, p. 367-376. 
een Overeenkomst ${ }^{28}$ is geregeld. Deze op grond van de oude derdepijlervoorzieningen van het Verdrag van Maastricht vastgestelde overeenkomst werd onlangs pas door de laatste lidstaat geratificeerd. Nog niet alle lidstaten hebben het uit 1996 stammende bijbehorende protocol geratificeerd dat het Hof van Justitie de mogelijkheid geeft prejudiciële vragen te beantwoorden.

Een groter probleem dan afwijkingen in de delictsomschrijving kunnen de verschillen zijn die tussen de lidstaten bestaan ten aanzien van algemene leerstukken van strafrechtelijke aansprakelijkheid. ${ }^{29}$ Een ambitieuze uitwerking van een algemeen deel specifiek voor de strafrechtelijke bescherming van de financiële belangen van de Unie, zoals een belangrijk onderdeel was van het Corpus Furis-project, ${ }^{30}$ is in de huidige plannen van de Commissie echter nog niet aanwezig. Wellicht ligt daaraan de verwachting ten grondslag dat de lidstaten dat zouden beschouwen als een te vergaande afwijking van het geldende nationale recht, dat zij zouden beschouwen als een belangrijke uitdrukking van fundamentele waarden in hun samenleving. Een eigen materieelrechtelijk regime voor de bestrijding van EU-fraude zou echter ook als een bescherming van nationale strafrechtelijke eigenheden kunnen worden gezien, omdat wezensvreemde uitgangspunten beperkt blijven in de supranationale regeling.

Het Commissievoorstel beperkt de materiële bevoegdheid van het Europees OM echter niet tot deze bepalingen van de toekomstige PIF-richtlijn. Het Europees OM zou ook bevoegd moeten zijn voor strafbare feiten die onlosmakelijk verbonden zijn met de strafbare feiten die bij deze richtlijn worden geharmoniseerd, als het in het belang van een goede rechtsbedeling is dat deze gezamenlijk worden opgespoord en vervolgd. ${ }^{31}$ Die impliciete bevoegdheid ontstaat slechts onder de voorwaarde dat de strafbare feiten die de financiële belangen van de Unie schaden van doorslaggevend gewicht zijn ten opzichte van de accessoire feiten, die bovendien op gelijke materiële feiten moeten zijn gebaseerd. De Nederlandse regering toonde zich 'vanuit een oogpunt van proportionaliteit' kritisch over deze regeling, en was van mening dat deze feiten, die slechts verbonden zijn met de strafbare feiten waar het werkelijk om gaat, niet onder het bereik van het Europees OM zouden moeten worden gebracht. ${ }^{32}$ Volgens de Commissie zou dat echter noodzakelijk voortvloeien uit de keuze die is gemaakt voor een exclusieve bevoegdheid voor het Europees OM in de strafrechtelijke bescherming van de financiële belangen van de Unie. Ook de Eerste Kamer toonde

28. Overeenkomst van 26 juli 1995 aangaande de bescherming van de financiële belangen van de Europese Gemeenschappen, Pb. EU 1995, C 316/48.

29. Daarover bijvoorbeeld J. Blomsma, Mens Rea and Defences in European Criminal Law (diss. Maastricht), Antwerpen: Intersentia 2012.

30. M. Delmas-Marty, Corpus Juris: portant dispositions pénales pour la protection des intérêts financiers de l'Union européenne, Parijs: Economica 1997; M. Delmas-Marty en J.A.E. Vervaele (red.), The Implementation of the Corpus Juris in the Member States, Antwerpen: Intersentia 2000-2001 (vier delen).

31. Art. 13.

32. Kamerstukken // 2012/13, 22112, nr. 1681, p. 6-7 zich kritisch hierover, zij voorziet ingewikkelde afstemmings- en prioriteringsvraagstukken. ${ }^{33}$

\section{Strafvorderlijke bevoegdheden}

Wat de strafvorderlijke bevoegdheden betreft die het Europees OM zou moeten uitoefenen in het kader van zijn werkzaamheden, is een andere richting gezocht dan voor de materiële competentie. Voordat duidelijk is in welke lidstaat een vervolging zal worden ingesteld, zal de Europese aanklager zelf immers een opsporingsonderzoek moeten kunnen instellen. In sommige gevallen kan het zo zijn dat een opsporingsonderzoek in een lidstaat is begonnen en wordt overgenomen door het Europees OM, maar zeker wanneer op Europees niveau sturing zal worden gegeven aan de fraudebestrijding, zullen er ook opsporingsonderzoeken worden begonnen door het Europees OM zelf. Het nationale recht dat daarop van toepassing zal zijn is moeilijk te bepalen, omdat het onderzoek zelf moet uitmaken in welke lidstaat kan worden vervolgd. Het Europees OM zou volgens de ontwerpverordening daarom zelf enkele bevoegdheden moeten kunnen uitoefenen zonder van bepaalde nationale voorschriften afhankelijk te zijn. Het gaat daarbij vooral om bevoegdheden tot het inwinnen van informatie ${ }^{34}$ en verzoeken tot het opheffen van de immuniteit van personen onder het Unierecht. ${ }^{35}$

Voor de meeste opsporingsbevoegdheden die het Europees OM zou kunnen gebruiken wordt geen zelfstandige regeling in de oprichtingsverordening getroffen, maar wordt verwezen naar het nationale recht. ${ }^{36}$ In de ontwerpverordening is wel een lijst opgenomen van opsporingsbevoegdheden en dwangmiddelen die de lidstaten zodanig in hun recht moeten opnemen dat het Europees OM deze kan uitoefenen. Wanneer het nationale recht daarin onverhoopt niet voorziet, mogen deze ook niet worden uitgeoefend, zodat het strafvorderlijke legaliteitsbeginsel niet wordt aangetast. Dat betekent dat de strafprocesrechtelijke bevoegdheden van het Europees OM tot op grote hoogte door het nationale recht worden bepaald, en niet door het Europese recht. ${ }^{37}$ De omvang en inhoud van strafvorderlijke bevoegdheden is echter in veel mindere mate geharmoniseerd dan bijvoorbeeld de strafbaarstelling van gedragingen die de financiële belangen van de Unie schaden. Op strafvorderlijk terrein zijn daarom grotere verschillen te verwachten tussen de lidstaten dan op materieelrechtelijk terrein. ${ }^{38} \mathrm{De}$ Europese Commissie probeert dat niet alleen te onder-

33. Kamerstukken / 2013/14, 33709, nr. C.

34. Art. 20 en 21

35. Art. 19.

36. Deze keuze wordt gemotiveerd onder verwijzing naar het proportionaliteitsbeginsel in overweging 19 van de ontwerpverordening.

37. De Nederlandse regering lijkt hier een sterkere verwevenheid te zien: Kamerstukken // 2012/13, 22112, nr. 1681, p. 7-8.

38. Op dit punt wordt door de commissie-Meijers gewezen op het belang van rechtszekerheid: 'Note Meijers Committee on the proposed Council Regulation on the establishment of the European Public Prosecutor's Office' (CM1315), p. 4 
vangen door een lijst met opsporingsbevoegdheden op te nemen in de ontwerpverordening, maar ook door enkele algemene bepalingen ten aanzien van het uitoefenen van die bevoegdheden te geven.

De opsporingsbevoegdheden van het Europees OM mogen slechts worden uitgeoefend bij een 'redelijk vermoeden' en wanneer met minder ingrijpende middelen het doel niet kan worden bereikt. ${ }^{39}$ Ook is voor de toepassing van de meest ingrijpende bevoegdheden ${ }^{40}$ altijd een voorafgaande schriftelijke en gemotiveerde rechterlijke toestemming vereist, ook als dat volgens het toepasselijke nationale recht niet nodig zou zijn. Voor de minder ingrijpende bevoegdheden ${ }^{41}$ is een dergelijke toestemming slechts noodzakelijk wanneer het nationale recht dat vereist. Daarnaast kan het Europees OM aan de bevoegde nationale rechter vragen om aanhouding of voorlopige hechtenis van de verdachte. ${ }^{42}$ Deze bepalingen van de ontwerpverordening laten daarmee veel concrete uitwerking over aan het nationale recht, wat vooral problematisch kan worden doordat het recht dat op de uitoefening van die opsporingsbevoegdheden van toepassing is, het recht is van de lidstaat waar de opsporingshandeling plaatsvindt. ${ }^{43}$ Dat heeft ook gevolgen voor de toelaatbaarheid van het vergaarde bewijs, dat uit verschillende lidstaten afkomstig kan zijn, in het uiteindelijke strafproces. In dit verband is het spijtig dat geen gebruik is gemaakt van het uitgebreide rechtsvergelijkende onderzoek dat met steun van de Commissie is verricht naar het strafprocesrecht in de EU, met als doel de opsporingsbevoegdheden van het Europees OM te kunnen uniformeren. ${ }^{44}$ Dat niet voor een dergelijke uniformering is gekozen, kan als reden hebben dat zelfstandige strafvorderlijke bevoegdheden voor het Europees OM voor veel lidstaten een te vergaande afwijking zouden betekenen van hun eigen strafprocesrecht. De wijze waarop de overheid inbreuken mag maken op fundamentele vrijheden wordt in veel lidstaten gezien als een materie die niet zonder meer uit handen mag worden gegeven. ${ }^{45} \mathrm{Op}$ dit punt vertoont de ontwerpverordening daarom sterk het karakter van een voortijdig compromis. Als de keuze gehandhaafd blijft om nationale strafvorderlijke bevoegdheden maatgevend te laten zijn voor het strafvorderlijk optreden, kan dat afdoen aan de effectiviteit waarmee het Europees OM zijn taken zal dienen uit te oefenen. ${ }^{46}$

39. Art. 26 lid 3. Het evenredigheidsbeginsel wordt ook als basisbeginse voor het optreden van het Europees OM genoemd in art. 11 lid 2.

40. Opgenomen in art. 26 lid 1 onder a $t / m$ j.

41. Opgenomen in art. 26 lid 1 onder $\mathrm{kt} / \mathrm{m} \mathrm{u}$.

42. Art. 26 lid 7.

43. Art. 11 lid 3.

44. Het eerste van twee delen is verschenen als K. Ligeti (red.), Toward a Prosecutor for the European Union. Vol. I. A Comparative Analysis, Oxford: Hart 2013.

45. Zie in dit verband M.L. Wade, 'A European public prosecutor: potential and pitfalls', Crime, Law and Social Change 2013, p. 439-486.

46. In die zin ook de Nederlandse regering: Kamerstukken II 2012/13, 22112, nr. 1681, p. 9 en K. Ligeti en M. Simonato, 'The European Public Prosecutor's Office: Towards a Truly European Prosecution Service?', New Journal of European Criminal Law 2013, p. 7-21.

\section{De vervolgingsbeslissing}

Er is echter één onderwerp waar de ontwerpverordening wel een duidelijk eigen signatuur draagt en niet verwijst naar het al dan niet geharmoniseerde nationale recht. Dat betreft de regeling van de vervolgingsbeslissing en de verschillende daarbij te nemen keuzes. De Europese Commissie stelt daarbij voorop dat het Europees OM zou moeten worden gebonden aan een verplichting tot vervolging, voor gevallen waarin een veroordeling haalbaar lijkt. Dat uitgangspunt is gebaseerd op de overtuiging dat de rechtszekerheid gediend is met een vervolgingsverplichting en dat er een zero tolerance-beleid dient te worden gevoerd ten opzichte van strafbare feiten die de financiële belangen van de Unie schaden. ${ }^{47}$ De voorgestelde regeling van de vervolgingsbeslissing gaat ervan uit dat het opsporingsonderzoek is uitgevoerd door een gedelegeerde Europese aanklager, ${ }^{48}$ waarbij niet helemaal duidelijk is wat er dient te gebeuren wanneer de Europese aanklager zelf het opsporingsonderzoek heeft geleid. ${ }^{49}$ Als een gedelegeerde Europese aanklager het opsporingsonderzoek afsluit, moet hij een samenvatting van de zaak en een ontwerptenlastelegging aan de Europese aanklager voorleggen, die dan verschillende keuzes kan maken. De Europese aanklager kan de gedelegeerde Europese aanklager opdragen de zaak voor de rechter te brengen, terug te verwijzen naar de opsporingsinstanties voor verder onderzoek, of te seponeren onder limitatief omschreven voorwaarden. De Europese aanklager kan ook zelf de zaak aan de rechter voorleggen, waarbij hij ook ter zitting kan optreden, een requisitoir kan houden en rechtsmiddelen kan instellen. ${ }^{50}$

De voorgestelde regeling van de vervolgingsbeslissing kent redelijk gedetailleerde uitwerkingen voor de verschillende beslissingen die rondom de vervolging moeten worden genomen. Het belang van deze bepalingen is groot, omdat ze voorrang hebben op de nationale bepalingen, hetgeen in de ontwerpverordening wellicht ten overvloede wordt gesteld. ${ }^{51} \mathrm{Zo}$ dient er een tenlastelegging te worden opgesteld waarbij een lijst moet worden gevoegd met het bewijsmateriaal dat in de nationale procedure zal worden aangevoerd. ${ }^{52}$ In het voorgestelde artikel over de instelling van de vervolging wordt niet uitdrukkelijk vermeld dat ook ontlastend bewijsmateriaal aan het dossier zal moeten worden toegevoegd. Het Europees $\mathrm{OM}$ zal wel verplicht zijn dat bewijsmateriaal te verzamelen. ${ }^{53}$ In het verlengde daarvan zou het logisch zijn te bepalen dat ook dit materiaal in het pro-

47. Zie overweging 20 .

48. Art. 27 lid 2.

49. Op basis van art. 18 lid 5 is dat mogelijk wanneer dat noodzakelijk is voor een efficiënt verloop van de opsporing of de vervolging wegens de ernst van het feit, specifieke omstandigheden die te maken hebben met de status van de vermoedelijke dader of de grensoverschrijdende dimensie van het onderzoek, het niet-beschikbaar zijn van nationale opsporingsinstanties of een verzoek van de bevoegde autoriteiten van de betrokken lidstaat.

50. Art. 27 lid 1 en 2 .

51. Art. 11 lid 3.

52. Art. 27 lid 3.

53. Art. 11 lid 5. 
cesdossier zal moeten worden gevoegd. Belangrijker nog zijn de bepalingen voor de keuze van de lidstaat waar de vervolging zal worden ingesteld, die door de Europese aanklager in nauwe samenwerking met de gedelegeerde Europese aanklager zal worden genomen. ${ }^{54}$ Daarbij dienen zij uit te gaan van een 'correcte rechtsbedeling', ${ }^{55}$ en daarmee bepalen zij 'welke nationale rechter bevoegd is' Dat lijkt te betekenen dat de aangezochte nationale rechter zich niet meer onbevoegd zal mogen verklaren. Als criteria voor de forumkeuze worden opgesomd: (a) de plaats waar het strafbare feit of, indien het om meerdere strafbare feiten gaat, de meerderheid van de strafbare feiten is gepleegd, (b) de gewone verblijfplaats van de verdachte, (c) de plaats waar het bewijs zich bevindt, en (d) de gewone verblijfplaats van de directe slachtoffers. Deze criteria hebben geen duidelijke onderlinge rangorde, wat zal betekenen dat het Europees OM een aanmerkelijke beleidsvrijheid zal hebben in de forumkeuze. Minder beleidsvrijheid bestaat er in de ontwerpverordening rondom het seponeren. Het Europees OM zou tot een sepot verplicht zijn wanneer de verdachte is overleden of aan hem amnestie of immuniteit is verleend, wanneer de gedragingen niet strafbaar blijken te zijn, de verjaringstermijn is verstreken of wanneer er een ne bis in idem-probleem is. ${ }^{56}$ Bevoegd, maar niet verplicht om te seponeren is het Europees $\mathrm{OM}$ in twee gevallen, namelijk wanneer het feit volgens de PIF-richtlijn is gekwalificeerd als 'licht strafbaar feit', of wanneer er onvoldoende bewijs is. ${ }^{57}$ De beperkte vrijheid om wegens beleidsredenen te seponeren wordt verzacht door de voorziene transactiemogelijkheden. De enige transactievoorwaarde die het Europees OM zou mogen aanbieden zou het betalen van een geldsom zijn, nadat bovendien de aangerichte schade is vergoed. Het financiële belang van deze regeling is groot. Reparatie van schade wordt bevorderd, hetgeen meestal zal bestaan in het aan de EU terugbetalen van een uitgekeerd subsidiebedrag. Ook zou de geldboete ten gunste van de EU moeten komen. ${ }^{58}$ De Commissie heeft bovendien voorgesteld dat het Europees OM zelf toezicht op de inning houdt en dat er geen rechterlijke toetsing mogelijk is op de afsluiting van de zaak nadat de geldboete is voldaan. ${ }^{59}$

\section{Besluit}

Op de belangrijkste onderwerpen is de ontwerpverordening van de Europese Commissie zo voorzichtig vormgegeven, dat men zich serieus kan afvragen of een Europees OM dat op deze basis wordt opgericht, wel effectief kan opereren. Daarvoor laten met name de regelingen van het toepasselijke materiële recht en de toe te passen opsporingsbevoegdheden te veel over aan

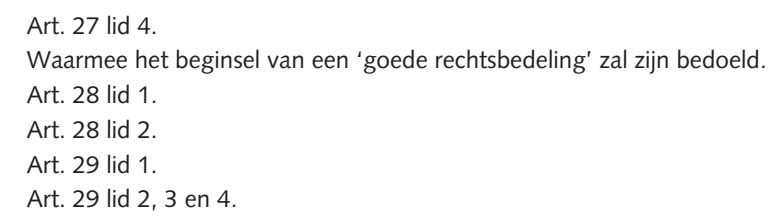

het nationale recht. Verder is het uitgangspunt van exclusieve bevoegdheid, hoewel ambitieus, een sterk complicerende factor, die onder meer als gevolg heeft dat een ingewikkelde regeling voor de behandeling van onlosmakelijk verbonden feiten is opgesteld, die tot veel afbakeningsproblemen aanleiding kan geven. De eveneens ingewikkelde, geintegreerde structuur van het Europees OM geeft blijk van de gedachte dat een sterke en gecentraliseerde vervolgingsinstantie niet goed te verkopen valt aan de lidstaten, die liever het idee hebben dat het uiteindelijk een nationale officier van justitie is die de opsporing en vervolging uitvoert. ${ }^{60}$ De bepaling dat de gedelegeerde Europese aanklager voorrang moet geven aan zijn Europese functie boven zijn nationale hoedanigheid laat echter weinig ruimte voor beïnvloeding van zijn taakuitoefening door het nationale Openbaar Ministerie. Doorzettingsmacht voor het Europees OM betekent dan ook dat niet langer op nationaal niveau kan worden besloten welke opsporingsprioriteiten worden gehanteerd. Het verlies van die sturingsmogelijkheden was een belangrijk argument voor het Nederlandse parlement om van oordeel te zijn dat het Commissievoorstel niet aan het subsidiariteitsbeginsel voldoet. ${ }^{61}$

Meer principiële tegenargumenten zijn er ook. De Eerste en Tweede Kamer stelden zich op het standpunt 'dat het strafrecht primair een nationale bevoegdheid is en dat derhalve opsporing en vervolging van deze delicten primair een taak is van de nationale autoriteiten'. ${ }^{62}$ Uiteindelijk zijn dergelijke overwegingen niet per se doorslaggevend voor het succes van een Europees OM. Het lijkt onvermijdelijk dat, als het al mogelijk is om tot oprichting van een Europees OM te komen, dat via nauwere samenwerking zal gebeuren. Wanneer de redenen om niet aan die samenwerking deel te nemen zijn gelegen in de angst voor het verlies van soevereiniteit heeft dat minder consequenties voor de effectiviteit van fraudebestrijding, dan wanneer lidstaten niet deelnemen aan de nauwere samenwerking omdat zij hun prioriteiten bij andere onderwerpen willen leggen dan de bestrijding van EU-fraude. ${ }^{63}$ Als het niet deelnemen aan de nauwere samenwerking betekent dat er geen vergelijkbaar niveau van fraudebestrijding ontstaat, is er immers nauwelijks meerwaarde boven de huidige situatie, waarin verschillende lidstaten voortvarend te werk gaan bij het opvolgen van OLAF-onderzoeken, maar enkele lidstaten structureel tekortschieten. ${ }^{64}$ Wanneer het uiteindelijk tot oprichting komt, moet een effectief Europees OM zo veel mogelijk lidstaten aan boord hebben, en bovendien doorzettingsmacht, een degelijke verantwoordingsstructuur en uniforme bevoegdheden bezitten om een succesvolle strafrechtelijke bescherming te bieden voor de financiële belangen van de Unie. Als

60. Kamerstukken // 2012/13, 22112, nr. 1681, p. 6.

61. Kamerstukken / 2013/14, 33709, nr. C; Kamerstukken || 2013/14, 33709, nr. 2.

62. Kamerstukken / 2013/14, 33709, nr. C; Kamerstukken || 2013/14, 33709, nr. 2.

63. Vgl. Kamerstukken I/ 2012/13, 22112, nr. 1681, p. 6.

64. Zie het Impact Assessment bij het Commissievoorstel: SWD(2013) 274. 
Nederland de bestrijding van fraude met EU-middelen een warm hart toedraagt, kan het niet tegelijkertijd de doorkruising van nationale prioriteitstellingen onaanvaardbaar vinden en om die reden niet deelnemen aan een eventuele nauwere samenwerking. 